Jurnal Medika Karya Ilmiah Kesehatan

Vol 6, No.2, November 2021

ISSN : 2654-945X (Online), 2541-4615 (Print)

Journal homepage : http://jurnal.itkeswhs.ac.id/index.php/medika

\title{
PERILAKU HIDUP BERSIH DAN SEHAT PADA TATANAN RUMAH TANGGA DI MASA PANDEMI COVID-19
}

\author{
Siti Mukaromah'1), Ariansyah'2), Atika Rahayu ${ }^{3)}$ \\ 1),2),3) Program Studi Pendidikan Profesi Ners Wiyata Husada Samarinda \\ Email : sitimukaromah@itkeswhs.ac.id
}

\begin{abstract}
ABSTRAK
Penyebaran coronavirus desease-19 (covid-19) beralih pada klaster keluarga, sehingga meningkatkan jumlah kasus covid-19 secara signifikan. Berdasarkan sifat virus corona yang menyerang sistem imun, salah satu upaya yang dilakukan berupa penerapan perilaku hidup bersih dan sehat (PHBS) pada tatanan rumah tangga. Di masa pandemi covid-19 ini, penerapan PHBS pada tatanan rumah tangga kurang terkontrol meskipun beberapa indikator PHBS tatanan rumah tangga telah terintegrasi ke dalam tindakan protokol kesehatan namun indikator lainnya belum terdeteksi. Tujuan penelitian untuk mengetahui penerapan perilaku hidup bersih dan sehat pada tatanan rumah tangga di masa pandemi covid-19. Rancangan penelitian berupa studi deskriptif dengan pendekatan survey. Responden berjumlah 197 kepala keluarga menggunakan rumus deskriptif kategorik dengan teknik accidental sampling. Hasil penelitian mayoritas keluarga telah melakukan seluruh indikator PHBS tatanan rumah tangga selama pandemi covid-19 meliputi, perilaku mencuci tangan dengan baik dan benar $(76,1 \%)$, mengkonsumsi makanan sehat sesuai dengan gizi seimbang $(53,8 \%)$, menggunakan jamban yang bersih dan sehat $(75,6 \%)$, melakukan aktivitas fisik setiap hari $(23,4 \%)$, membuang sampah pada tempatnya $(67 \%)$, tidak merokok $(51 \%)$, menjaga kebersihan lingkungan sekitar rumah $(72,6 \%)$, menghindari dan mengelola stress dengan baik dalam kehidupan sehari-hari $(51,8 \%)$, dan istirahat yang cukup $(55,8 \%)$. Kedisiplinan keluarga dalam penerapan PHBS pada tatanan rumah tangga selama pandemi covid-19 perlu ditingkatkan terutama aktifitas fisik guna meningkatkan imunitas tubuh, sehingga membantu mencegah paparan covid-19 di lingkungan keluarga maupun masyarakat.
\end{abstract}

Kata Kunci : PHBS, tatanan rumah tangga, klaster keluarga

\section{*Corresponding Author :}

Siti Mukaromah

Program Studi Pendidikan Profesi Ners

ITKES Wiyata Husada Samarinda, Indonesia

Email : sitimukaromah@itkeswhs.ac.id 
Jurnal Medika Karya IImiah Kesehatan

Vol 6, No.2, November 2021

ISSN : 2654-945X (Online), 2541-4615 (Print)

Journal homepage : http://jurnal.itkeswhs.ac.id/index.php/medika

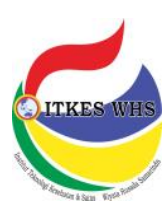

\section{PENDAHULUAN}

Coronavirus disease 2019 (Covid-19) adalah penyakit pernafasan yang disebabkan oleh infeksi virus bernama Severe Acute Respiratory Syndrome Coronavirus 2 (SARS-CoV-2) yang menyerang bagian pernafasan. Penularan dapat terjadi dengan melalui percikan/droplet saat batuk, bersin, saat berbicara, melalui kontak langsung, serta dapat melalui benda di sekitar (Humaira, 2020). Orang yang terinfeksi covid-19 tidak semuanya menunjukkan gejala disebut orang tanpa gejala (OTG), sehingga sangat berisiko bagi para lansia maupun orang-orang yang memiliki penyakit kormobid atau dibawah pengawasan medis (CDC, 2021).

Penyebaran covid-19 lebih banyak ditemukan pada klaster keluarga. Persepsi dan keyakinan yang keliru setiap anggota keluarga terhadap covid-19 menjadi tantangan besar dalam upaya pencegahan penyebaran covid-19. Klaster keluarga terjadi karena adanya seseorang yang tertular, lalu menularkannya kepada anggota keluarga lain. Terdapat titik lengah di lingkungan rumah yang menyebabkan keluarga terpapar covid-19, yaitu, makan bersama yang tidak serumah, menginap di rumah teman/kerabat, memanggil tukang jasa perbaikan teknis maupun tukang pijat ke rumah, menerima tamu, membiarkan anak bermain dengan teman-temannya, kumpul keluarga/arisan, pegawai rumah yang pulang pergi, berbelanja ke pasar atau tukang sayur dan pergi keluar tanpa protokol kesehatan. Aktivitas di luar rumah yang rentan terpapar covid-19 meliputi makan bersama di luar rumah, ke tempat ibadah tanpa menjalankan protokol kesehatan, menghadiri pesta, acara pernikahan, dan pemakaman (Litha, 2021).

Salah satu upaya pencegahan penyebaran covid-19 di klaster keluarga adalah penerapan perilaku hidup bersih dan sehat (PHBS). Tujuan dari PHBS di masa pandemi adalah mewujudkan kemampuan pola hidup bersih dan sehat terutama pada keluarga dalam melakukan pencegahan penyebaran covid-19 di lingkungan keluarga maupun masyarakat (Fadhliyah, 2020). Ada sembilan indikator acuan keberhasilan dalam mencapai rumah tangga yang sehat selama masa pandemi, yaitu membiasakan mencuci tangan dengan sabun dan air bersih, mengonsumsi makanan sehat, menggunakan jamban yang bersih, olahraga secara teratur, membuang sampah pada tempatnya, tidak merokok, membersihkan lingkungan, menghindari dan kelola stress, serta istirahat yang cukup. Apabila salah satu indikator acuan keberhasilan PHBS selama masa pandemi tidak terlaksana secara keseluruhan, maka kategori PHBS dalam keluarga tersebut dapat dikatakan tidak dapat memutus rantai penyebaran covid-19 di Indonesia (Nurwita, 2020).

PHBS merupakan salah satu bagian misi dari rencana strategis pembangunan kesehatan kota/kabupaten dengan ruang lingkup kegiatan pada upaya kesehatan masyarakat. PHBS pada tatanan rumah tangga merupakan salah satu indikator keberhasilan capaian upaya kesehatan bersumber masyarakat (UKBM). Kegiatan UKBM selama pandemi di wilayah puskesmas mengalami keterbatasan sehingga meminimalkan ketercapaian target layanan UKBM. Beberapa indikator PHBS pada tatanan rumah tangga terintegrasi ke dalam tindakan protokol kesehatan maupun kesehatan lingkungan menyesuaikan dengan situasi covid-19, namun indikator lainnya belum terdeteksi. Setiap tahun periodik ada kenaikan target capaian rumah tangga ber-PHBS sebesar $10 \%$, yang dimulai dari target capaian tahun 2015 sebesar $60 \%$, pada tahun 2019 target capaian rumah tangga ber-PHBS sebesar $70 \%$. Tidak adanya data penerapan PHBS rumah tangga maupun kurang berjalannya kegiatan UKBM berdampak pada penurunan target capaian serta kurang terkontrolnya penerapan PHBS tatanan rumah

\section{*Corresponding Author :}

Siti Mukaromah

Program Studi Pendidikan Profesi Ners

ITKES Wiyata Husada Samarinda, Indonesia

Email : sitimukaromah@itkeswhs.ac.id 
Jurnal Medika Karya IImiah Kesehatan

Vol 6, No.2, November 2021

ISSN : 2654-945X (Online), 2541-4615 (Print)

Journal homepage : http://jurnal.itkeswhs.ac.id/index.php/medika

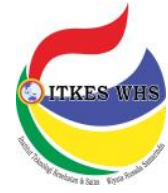

tangga sebagai salah satu upaya pencegahan penyebaran covid- 19 .

Hasil studi pendahuluan yang dilakukan pada bulan Juli 2021, didapatkan informasi dari pimpinan puskesmas Muara Rapak bahwa wilayah puskesmas Muara Rapak Balikpapan terdapat zona hijau, kuning, dan merah berdasarkan sebaran kasus covid-19. Namun, dikarenakan situasi belum dapat dikendalikan sepenuhnya maka sewaktu-waktu zona hijau tersebut dapat menjadi zona kuning ataupun merah. Meskipun kegiatan sosialisasi ke masyarakat terkait pencegahan covid-19 dengan penerapan protokol kesehatan maupun vaksinasi terus diberlangsungkan dan diberlakukannya monitoring secara intens oleh pihak puskesmas bekerjasama dengan pihak kelurahan setempat terhadap perkembangan covid-19 di wilayah puskesmas Muara Rapak, hal tersebut belum dapat mengendalikan situasi jika tanpa adanya kesadaran diri dari masyarakat setempat untuk menjalankan langkah-langkah pencegahan. Masyarakat di wilayah puskesmas Muara Rapak sudah menerapkan PHBS sejak sebelum pandemi, namun pada masa pandemi ini meskipun masyarakat sudah melakukan protokol kesehatan secara ketat, masih ada capaian kurang dari target capaian berdasarkan hasil survei mawas diri, meliputi penyakit batuk pilek sebesar $48 \%>0 \%$, pemberian ASI ekslusif sebesar $73 \%<80 \%$, pembuangan tempat sampah tidak tertutup sebesar $42,5 \%>0 \%$, rumah tanpa ventilasi $10,63 \%>0 \%$, penggunaan jamban sehat sebesar $88 \%<100 \%$, dan anggota keluarga dengan kebiasaan merokok sebesar $55,63 \%>0 \%$.

Program PHBS juga merupakan salah satu misi program prioritas dari rencana strategis pembangunan kesehatan kota Balikpapan Tahun 2016-2021 melalui kegiatan upaya kesehatan masyarakat dengan target capaian sebesar $98,30 \%$ pada awal tahun 2020, sedangkan capaian program PHBS melalui cakupan jamban sehat maupun rumah sehat berdasarkan profil kesehatan Dinkes Kota Balikpapan tahun 2019 sebesar 89,8\%. Berdasarkan hal tersebut, maka perlu ada kajian analisis tentang perilaku hidup bersih dan sehat pada tatanan rumah tangga di masa pandemi covid-19, sehingga diketahui penerapan PHBS di tingkat keluarga guna mendukung ketercapaian Indonesia Sehat tahun 2025.

\section{METODE PENELITIAN}

Rancangan penelitian ini adalah penelitian kuantitatif menggunakan studi deskriptif dengan pendekatan survey. Sampel penelitian sejumlah 197 kepala keluarga di wilayah puskesmas Muara Rapak Balikpapan dengan teknik accidental sampling. Data diperoleh melalui kuesioner menggunakan aplikasi google form, dengan hasil uji validitas masing-masing komponen variabel berkisar pada nilai $r$ hitung $(0,766-0,983)>r$ tabel $(0,279)$ dan uji reliabilitas masing-masing komponen variabel berkisar pada nilai $\alpha(0,818-0,983)>0,60$. Teknik analisis data yang digunakan berupa analisis univariat yang menjelaskan distribusi frekuensi masing-masing komponen PHBS pada tatanan rumah tangga.

\section{HASIL DAN PEMBAHASAN}

TABEL 1

DISTRIBUSI KARAKTERISTIK RESPONDEN

\begin{tabular}{|c|c|c|c|}
\hline Karakteristik N & Min & Max & Mean \\
\hline $\begin{array}{ll}\text { Usia } & 197\end{array}$ & 23 & 84 & $50,68 \quad 13,31$ \\
\hline Jenis Kelamin & (f) & & $(\%)$ \\
\hline Perempuan & 61 & & 31 \\
\hline Laki-laki & 136 & & 69 \\
\hline Total & 197 & & 100 \\
\hline \multicolumn{4}{|l|}{ Pendidikan } \\
\hline Tidak sekolah & 2 & & 1 \\
\hline SD & 35 & & 17,8 \\
\hline SMP & 31 & & 15,7 \\
\hline SMA & 110 & & 55,8 \\
\hline Sarjana & 19 & & 9,6 \\
\hline Total & 197 & & 100 \\
\hline
\end{tabular}

\section{*Corresponding Author :}

Siti Mukaromah

Program Studi Pendidikan Profesi Ners

ITKES Wiyata Husada Samarinda, Indonesia

Email : sitimukaromah@itkeswhs.ac.id 
Jurnal Medika Karya IImiah Kesehatan

Vol 6, No.2, November 2021

ISSN : 2654-945X (Online), 2541-4615 (Print)

Journal homepage : http://jurnal.itkeswhs.ac.id/index.php/medika

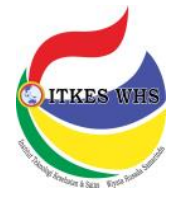

Didapatkan rata-rata responden berusia 51 tahun, mayoritas responden laki-laki yaitu sebanyak 136 kepala keluarga (69\%) dan berpendidikan SMA sebanyak 110 kepala keluarga (55,8\%). Responden sebagai pihak tertua sekaligus berperan sebagai pengambil keputusan dengan kemampuan kognitif yang baik, maka mampu bertanggung jawab terhadap aturan yang ditetapkan di lingkungan rumah tangga, salah satunya terkait dengan penerapan PHBS.

TABEL 2

DISTRIBUSI RESPONDEN BERDASARKAN PENERAPAN PHBS PADA TATANAN RUMAH TANGGA SELAMA PANDEMI COVID-19

\begin{tabular}{|c|c|c|}
\hline Cuci Tangan & (f) & (\%) \\
\hline Tidak Dilakukan & 1 & 0,5 \\
\hline Dilakukan Sebagian & 46 & 23,4 \\
\hline Dilakukan Seluruhnya & 150 & 76,1 \\
\hline Total & 197 & 100 \\
\hline \multicolumn{3}{|c|}{ Konsumsi Makanan Sehat } \\
\hline Tidak Dilakukan & 7 & 3,6 \\
\hline Dilakukan Sebagian & 84 & 42,6 \\
\hline Dilakukan Seluruhnya & 106 & 53,8 \\
\hline Total & 197 & 100 \\
\hline \multicolumn{3}{|c|}{ Penggunaan Jamban Sehat } \\
\hline Tidak Dilakukan & 6 & 3 \\
\hline Dilakukan Sebagian & 42 & 21,3 \\
\hline Dilakukan Seluruhnya & 149 & 75,6 \\
\hline Total & 197 & 100 \\
\hline \multicolumn{3}{|c|}{ Kebiasaan Olahraga } \\
\hline Tidak Dilakukan & 35 & 17,8 \\
\hline Dilakukan Sebagian & 116 & 58,9 \\
\hline Dilakukan Seluruhnya & 46 & 23,4 \\
\hline Total & 197 & 100 \\
\hline \multicolumn{3}{|c|}{ Kebiasaan Buang Sampah } \\
\hline Dilakukan Sebagian & 65 & 33 \\
\hline Dilakukan Seluruhnya & 132 & 67 \\
\hline Total & 197 & 100 \\
\hline \multicolumn{3}{|c|}{ Kebiasaan Tidak Merokok } \\
\hline Tidak Dilakukan & 17 & 8,6 \\
\hline Dilakukan Sebagian & 129 & 65,5 \\
\hline Dilakukan Seluruhnya & 51 & 25,9 \\
\hline Total & 197 & 100 \\
\hline
\end{tabular}

\begin{tabular}{lcc}
\hline Kebersihan Lingkungan & (f) & (\%) \\
\hline Tidak Dilakukan & 1 & 0,5 \\
Dilakukan Sebagian & 53 & 26,9 \\
Dilakukan Seluruhnya & 143 & 72,6 \\
\hline \multicolumn{1}{c}{ Total } & 197 & 100 \\
\hline \multicolumn{1}{c}{ Pengelolaan Stres } & & \\
\hline Tidak Dilakukan & 7 & 3,6 \\
Dilakukan Sebagian & 88 & 44,7 \\
Dilakukan Seluruhnya & 102 & 51,8 \\
\hline \multicolumn{1}{c}{ Total } & 197 & 100 \\
\hline Kecukupan Istirahat & & \\
\hline Tidak Dilakukan & 10 & 5,1 \\
Dilakukan Sebagian & 77 & 39,1 \\
Dilakukan Seluruhnya & 110 & 55,8 \\
\hline \multicolumn{1}{c}{ Total } & 197 & 100 \\
\hline
\end{tabular}

Didapatkan mayoritas keluarga telah melakukan seluruh komponen indikator PHBS tatanan rumah tangga selama pandemi covid-19 meliputi, perilaku mencuci tangan dengan baik dan benar (76,1\%), mengkonsumsi makanan sehat sesuai dengan gizi seimbang $(53,8 \%)$, menggunakan jamban yang bersih dan sehat $(75,6 \%)$, melakukan aktivitas fisik setiap hari $(23,4 \%)$, membuang sampah pada tempatnya (67\%), tidak merokok (51\%), menjaga kebersihan lingkungan sekitar rumah $(72,6 \%)$, menghindari dan mengelola stress dengan baik dalam kehidupan sehari-hari $(51,8 \%)$, dan istirahat yang cukup $(55,8 \%)$. Penerapan PHBS oleh setiap individu di dalam rumah tangga menggambarkan upaya untuk pencegahan terhadap paparan penyakit dan peningkatan imunitas tubuh. Pemenuhan penerapan seluruh komponen indikator PHBS tatanan rumah tangga dapat membantu pencegahan penyebaran covid-19 di lingkup individu dan masyarakat.

\section{Perilaku Hidup Bersih dan Sehat pada Tatanan Rumah Tangga di Masa Pandemi Covid-19}

Penerapan perilaku hidup bersih dan sehat (PHBS) merupakan upaya yang dilakukan individu dengan penuh kesadaran sehingga mampu mempertahankan kesehatan

\section{*Corresponding Author :}

Siti Mukaromah

Program Studi Pendidikan Profesi Ners

ITKES Wiyata Husada Samarinda, Indonesia

Email : sitimukaromah@itkeswhs.ac.id 
Jurnal Medika Karya IImiah Kesehatan

Vol 6, No.2, November 2021

ISSN : 2654-945X (Online), 2541-4615 (Print)

Journal homepage : http://jurnal.itkeswhs.ac.id/index.php/medika

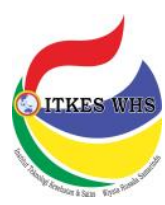

dan meningkatkan status kesehatan.

Penerapan PHBS di masa pandemi covid-19 bertujuan untuk meningkatkan imunitas individu guna mencegah penularan maupun penyebaran penyakit covid-19. Adapun uraian penerapan indikator PHBS berdasarkan hasil penelitian sebagai berikut:

\section{Perilaku Mencuci Tangan}

Keluarga yang melakukan seluruh komponen indikator perilaku mencuci tangan sebanyak 150 keluarga $(76,1 \%)$. Seluruh anggota keluarga mencuci tangan menggunakan air bersih dan melakukan kegiatan tersebut sesuai dengan tahapan cuci tangan 6 langkah benar. Keluarga juga menerapkan mencuci tangan sebelum dan sesudah makan atau setelah beraktivitas. Kegiatan tersebut dilakukan oleh keluarga karena telah menyadari jika mencuci tangan dapat mencegah penyebaran penyakit terutama dalam masa pandemi covid-19.

Kesadaran diri keluarga melakukan cuci tangan sesuai dengan hasil penelitian Benny (2020) terkait gambaran Perilaku Hidup Bersih dan Sehat (PHBS) dalam pencegahan penularan covid-19 dimana keluarga mengetahui jika mencuci tangan setelah melakukan aktivitas dapat mengurangi penularan bakteri atau virus yang didapatkan dari luar rumah.

Keluarga yang hanya melakukan sebagian komponen dari indikator perilaku mencuci tangan berjumlah 46 keluarga $(23,4 \%)$. Keluarga biasa mencuci tangan hanya saat setelah dari luar rumah saja, tidak menerapkan tahapan mencuci tangan dengan 6 langkah, hanya sekedar air yang mengalir dan memakai sabun saja, serta tidak memakai tisu atau penghalang agar tangan yang sudah bersih tidak menyentuh kran air.

Meskipun mencuci tangan dengan air yang mengalir dan memakai sabun dirasa cukup membersihkan tangan, namun penerapan cuci tangan yang tidak dilakukan pada setiap waktu dapat berisiko terpapar penyakit. Perilaku mencuci tangan yang dilakukan sebagian oleh keluarga tersebut juga tidak sejalan dengan pernyataan Lia (2020) bahwa anjuran cuci tangan bukan hanya diperuntukkan ketika diluar rumah namun juga didalam rumah, misal ketika memesan makanan dari luar, setelah menerima paket sebelum dan sesudah makan, setelah beraktivitas dan sebagainya. Selain itu juga senantiasa memastikan mencuci tangan selama 40-60 detik dan tangan yang sudah bersih tidak menyentuh kran air.

Adapun keluarga yang tidak melakukan komponen indikator perilaku mencuci tangan berjumlah 1 keluarga (0,5\%). Keluarga mengalami keterbatasan pasokan air di lingkungan rumahnya, sehingga keluarga tersebut mencuci tangan dengan menggunakan air hujan yang kurang bersih, tidak memakai sabun dan tidak sesuai langkah mencuci tangan sesuai anjuran WHO.

Meskipun keluarga memiliki keterbatasan, bukan berarti keluarga tidak dapat melakukan cuci tangan. Keluarga yang tidak menerapkan perilaku mencuci tangan menggambarkan bahwa perilaku keluarga tersebut tidak menerapkan tindakan kesehatan yang seharusnya dapat dilakukan. Hal tersebut juga tidak sejalan dengan pernyataan Nisal (2019) bahwa mencuci tangan dengan air bersih dan sabun merupakan suatu intervensi kesehatan yang paling hemat namun sangat bermanfaat karena bertujuan untuk membunuh kuman penyakit sehingga tangan terbebas dari kuman.

Pada masa pandemi covid-19 ini, perilaku mencuci tangan merupakan salah satu langkah protokol kesehatan yang wajib dilakukan oleh setiap individu yang ada di dalam keluarga maupun masyarakat sebagai langkah pencegahan terpapar virus covid-19. Hal ini tercantum pada peraturan Kemenkes RI nomor HK.01.07/MENKES/382/2020 yang memuat perlindungan kesehatan individu dengan tindakan salah satunya adalah membersihkan

\section{*Corresponding Author :}

Siti Mukaromah

Program Studi Pendidikan Profesi Ners

ITKES Wiyata Husada Samarinda, Indonesia

Email : sitimukaromah@itkeswhs.ac.id 
Jurnal Medika Karya IImiah Kesehatan

Vol 6, No.2, November 2021

ISSN : 2654-945X (Online), 2541-4615 (Print)

Journal homepage : http://jurnal.itkeswhs.ac.id/index.php/medika

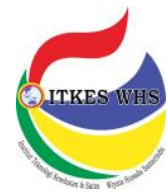

tangan secara teratur dengan cuci tangan pakai sabun dan air mengalir atau menggunakan cairan antiseptik berbasis alkohol/handsanitizer serta selalu menghindari menyentuh mata, hidung, maupun mulut dengan tangan yang tidak bersih karena kemungkinan terkontaminasi virus covid-19 melalui droplet (Kemenkes, 2020).

\section{Perilaku Mengkonsumsi Makanan Sehat}

Keluarga yang melakukan seluruh komponen indikator perilaku mengkonsumsi makanan sehat sebanyak 106 keluarga $(53,8 \%)$. Hal ini menunjukkan bahwa rata-rata keluarga berupaya memakan makanan yang sehat dan bergizi sebagai usaha pencegahan paparan covid-19. Apa yang dilakukan oleh keluarga tersebut sejalan dengan peraturan Kemenkes RI nomor HK.01.07/MENKES/382/ 2020 yang memuat perlindungan kesehatan individu dengan tindakan salah satunya adalah mengkonsumsi gizi seimbang sebagai salah satu kegiatan PHBS yang dapat meningkatkan daya tahan tubuh.

Keluarga yang hanya melakukan sebagian komponen indikator perilaku mengkonsumsi makanan sehat berjumlah 84 keluarga $(42,6 \%)$. Keluarga hanya dapat memakan makanan bergizi setiap seminggu dua kali atau sekali saja. Hal ini menunjukkan upaya keluarga untuk mempertahankan kesehatannya meskipun dalam keterbatasan, sebagaimana pernyataan Benny (2020), bahwa menjaga asupan makanan yang bersih dan sehat juga merupakan salah satu bentuk upaya untuk meningkatkan kesehatan dan daya tahan tubuh, guna meminimalkan paparan covid-19.

Keluarga yang tidak melakukan perilaku mengkonsumsi makanan sehat berjumlah 7 keluarga $(3,6 \%)$ karena keluarga memiliki keterbatasan biaya untuk membeli makanan-makanan yang sehat dan bergizi, biasanya keluarga hanya memakan karbohidrat saja tanpa ada sayuran. Hal tersebut menunjukkan bahwa faktor ekonomi berperan penting dalam pemenuhan makanan sehat. Namun, sumber makanan sehat tidak selalu berharga mahal. Setiap keluarga dapat menggunakan alternatif bahan pangan yang sehat yang memenuhi kebutuhan karbohidrat, protein, lemak, vitamin dan mineral yang didapat di sekitar keluarga. Pada Permenkes No.41 tahun 2014 tentang Pedoman Gizi Seimbang diuraikan tentang rincian sumber bahan makanan sehat yang dapat dijadikan sebagai bahan subtitusi atau pengganti. Selain itu, juga dinyatakan bahwa upaya menjaga ketahanan tubuh berupa konsumsi makanan sehat, meliputi sayuran dan buah-buahan yang merupakan sumber berbagai vitamin, karbohidrat, lemak, dan mineral, serta lauk pauk yang mengandung protein (Kemenkes, 2017).

\section{Perilaku Menggunakan Jamban Sehat}

Keluarga yang melakukan seluruh komponen indikator perilaku menggunakan jamban sehat sebanyak 149 keluarga $(75,6 \%)$. Data tersebut menunjukkan bahwa sudah banyak keluarga yang menggunakan jamban sehat dan mempunyai perilaku yang baik dalam penggunaan jamban serta memahami akan pentingnya kebersihan jamban.

Penggunaan jamban yang baik meliputi menyiram dengan air yang cukup setiap kali selesai buang tinja sehingga kotoran tidak tampak lagi, lantai jamban selalu bersih dan tidak ada genangan air, membersihkan jamban secara teratur sehingga ruang jamban selalu dalam keadaan bersih, di dalam jamban tidak terlihat ada kotoran dan serangga (kecoa, lalat) maupun tikus yang berkeliaran, menyediakan alat pembersih dan bila ada kerusakan segera diperbaiki, mencuci tangan dengan sabun dan air bersih sesudah BAB/BAK. Perilaku tersebut mendukung pemenuhan standar dan persyaratan kesehatan karena tidak mengakibatkan terjadinya penyebaran langsung akibat pembuangan kotoran manusia, dan dapat mencegah vektor pembawa transmisi penyakit dari tinja (Kemenkes, 2014).

\section{*Corresponding Author :}

Siti Mukaromah

Program Studi Pendidikan Profesi Ners

ITKES Wiyata Husada Samarinda, Indonesia

Email : sitimukaromah@itkeswhs.ac.id 
Jurnal Medika Karya IImiah Kesehatan

Vol 6, No.2, November 2021

ISSN : 2654-945X (Online), 2541-4615 (Print)

Journal homepage : http://jurnal.itkeswhs.ac.id/index.php/medika

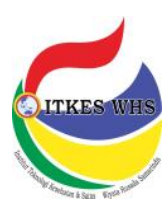

Keluarga yang melakukan sebagian komponen indikator perilaku menggunakan jamban sehat berjumlah 42 keluarga $(21,3 \%)$. Keluarga menggunakan jamban untuk BAK/BAB namun keluarga jarang membersihkan jamban tersebut. Keluarga membersihkan jamban tersebut ketika waktu kotor saja. Peran keluarga dalam menjaga sanitasi lingkungan sangat mendukung upaya pergerakan sanitasi total berbasis masyarakat (STBM) guna mencegah penyebaran penyakit berbasis lingkungan akibat kontaminasi kotoran manusia sebagai sumber penyakit berkelanjutan. Oleh karena itu, kebersihan sanitasi dapat mendukung upaya peningkatan kesehatan terutama pada saat pandemi covid-19 saat ini.

Adapun 6 keluarga dengan presentase $3 \%$ tidak memiliki jamban di rumah melainkan menggunakan fasilitas jamban umum. Pemanfaatan jamban keluarga dipengaruhi oleh pengetahuan tentang jamban sehat dan kebiasaan keluarga maupun masyarakat. Memiliki jamban sehat merupakan salah satu fasilitas sanitasi dasar yang sangat penting dalam keluarga karena dengan adanya jamban, berbagai macam penyakit dapat terisolasi sehingga mencegah terjadinya penyebaran penyakit lainnya (Widia, 2020). Permenkes RI No.3 Th 2014 tentang Sanitasi Total Berbasis Masyarakat menyatakan bahwa jamban sehat harus dibangun, dimiliki, dan digunakan oleh keluarga dengan penempatan (di dalam atau di luar rumah) yang mudah dijangkau oleh penghuni rumah, karena efektif memutus mata rantai penularan penyakit.

\section{Perilaku Aktivitas Fisik (Olahraga)}

Keluarga yang melakukan seluruh komponen indikator perilaku aktivitas fisik (olahraga) sebanyak 46 keluarga $(23,4 \%)$. Keluarga beranggapan bahwa beraktivitas fisik atau olahraga dapat menjaga daya tahan tubuh dan kesehatan tubuh sehingga mencegah paparan covid-19.

\section{*Corresponding Author :}

Siti Mukaromah

Program Studi Pendidikan Profesi Ners

ITKES Wiyata Husada Samarinda, Indonesia

Email : sitimukaromah@itkeswhs.ac.id
Keluarga yang hanya melakukan sebagian komponen indikator perilaku aktifitas fisik berjumlah 116 keluarga (58,9\%). Keluarga berolahraga ketika hari libur saja karena keterbatasan waktu yang dimiliki serta banyaknya aktifitas pekerjaan lain yang dilakukan oleh keluarga. Sedangkan keluarga yang tidak melakukan aktifitas fisik (olahraga) berjumlah $35(17,8 \%)$, karena ketidaktahuan keluarga tentang pentingnya olahraga dimasa pandemi covid-19 serta keluarga yang tidak pernah mau melakukan olahraga dikarenakan kelelahan setelah bekerja dan takut terpapar covid-19 ketika berada diluar rumah (Benny, 2020).

Aktivitas fisik berupa olah raga, dapat dilakukan minimal 30 menit sehari, misalnya dengan jalan kaki, jogging, bersepeda, yoga. Olahraga dilakukan dengan prinsip BBT (Baik, Benar, Terukur, dan Teratur). Prinsip Baik yaitu melakukan aktifitas fisik sesuai dengan kemampuannya. Pilih olahraga yang disukai, aman, mudah, dan sesuai kondisi fisik. Prinsip Benar yaitu aktifitas yang dilakukan secara bertahap mulai dari pemanasan selama 5-10 menit dan diakhiri dengan pendinginan atau peregangan selama 5 menit. Prinsip Terukur yaitu aktifitas fisik yang dapat diukur intensitas dan waktunya. Aktifitas fisik dilakukan secara bertahap hingga mencapai 30 menit, tidak memaksakan diri, dilakukan sebelum makan atau 2 jam sesudah makan, diawali dengan pemanasan dan peregangan, jika hendak jalan/lari menggunakan sepatu yang enak dan nyaman dipakai. Prinsip Teratur yaitu aktifitas fisik yang dilakukan secara teratur sebanyak 3-5 kali dalam seminggu (Kemenkes, 2019).

Manfaat olahraga antara lain meningkatkan sensitivitas insulin, fungsi kognitif, dan respons terhadap stres psikososial, serta membantu pencegahan depresi maupun penurunan risiko penyakit kardiovaskuler dan metabolik yang tentunya akan menurunkan tingkat keparahan covid-19 akibat komorbid, serta memperbaiki kualitas hidup pada 
Jurnal Medika Karya IImiah Kesehatan

Vol 6, No.2, November 2021

ISSN : 2654-945X (Online), 2541-4615 (Print)

Journal homepage : http://jurnal.itkeswhs.ac.id/index.php/medika

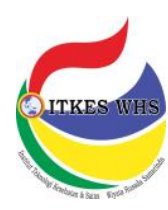

umumnya. Selain itu, olahraga rutin bermanfaat bagi usia dewasa menengah dan tua untuk memperbaiki kualitas tidur. Olahraga (khususnya olahraga aerobik) membantu melindungi tubuh melawan covid-19 dengan cara meningkatkan elemen imunitas tertentu yang dapat memicu mobilitas limfosit, guna menurunkan tingkat keparahan penyakit (Dyah, 2020).

\section{Perilaku Membuang Sampah}

Keluarga yang melakukan seluruh komponen indikator perilaku membuang sampah sebanyak 132 keluarga (67\%). Keluarga membuang sampah pada tempat sampah yang tersedia di rumah dan membuang sampah di tempat pembuangan sementara (TPS) sehingga sampah di rumah tidak menumpuk. Keluarga juga memilah sampah. Keluarga mengetahui jika membuang sampah pada tempatnya dapat bermanfaat bagi kesehatan karena terhindar dari bau yang tidak sedap maupun kontaminasi vektor pembawa penyakit, serta dapat menjadikan lingkungan bersih dan terlihat asri.

Kemampuan keluarga dalam pengelolaan sampah menunjukkan upaya keluarga dalam perubahan perilaku hidup sehat (Edi, 2020). Hal ini sesuai dengan uraian kegiatan pengamanan sampah rumah tangga berdasarkan Permenkes RI No.3 Th 2014 meliputi sampah tidak boleh ada di dalam rumah dan harus dibuang setiap hari, pemilahan berupa sampah organik dan non organik sehingga perlu tempat sampah yang berbeda, tempat sampah tertutup rapat, pengumpulan sampah dilakukan pengambilan dan pemindahan dari rumah tangga ke tempat penampungan sementara atau tempat pengolahan sampah terpadu selanjutnya diangkut ke tempat pemrosesan akhir (Kemenkes, 2014).

Pengelolaan sampah pada masa pandemi covid-19 perlu memperhatikan hal-hal sebagai berikut: 1) memilah sampah menjadi 3 jenis (organik, anorganik, dan medis/infeksius), memberi label sampah medis/infeksius agar lingkungan dan petugas pengelola sampah lebih waspada; 2) memproses sampah organik agar tidak menumpuk, agar tidak mengundang hama atau menjadi media pertumbuhan bakteri berbahaya bagi manusia; 3) menggunakan material yang bisa digunakan berulang kali, misal masker yang bisa dicuci, didesinfeksi, dan dijemur; 4) membawa kotak bekal dan botol minuman sendiri, guna mengurangi produksi sampah kemasan makanan sekali pakai dan mencegah penyebaran penyakit; 5) memilah sampah daur ulang dan menjaga jarak saat memastikan daur ulang sampah melalui bank sampah maupun jasa pengangkutan sampah (Bahraini, 2020).

Keluarga yang hanya melakukan sebagian komponen indikator perilaku membuang sampah berjumlah 65 keluarga (33\%). Keluarga membuang sampah pada tempatnya namun tidak pernah memilah sampah organik dan non organik dengan alasan keterbatasan tempat sampah yang dimiliki dan menganggap bahwa kegiatan memilah sampah tidak perlu dilakukan karena pada akhirnya akan tercampur jadi satu setelah di tempat pembuangan akhir.

Persepsi seseorang dapat mempengaruhi perilaku kesehatan seseorang sebagaimana pernyataan Nugraha (2018) bahwa persepsi masyarakat tentang pengelolaan sampah rumah tangga yang semakin baik menyebabkan tingkat partisipasi dalam pengelolaan sampah rumah tangga semakin tinggi. Demikian pula sebaliknya, jika persepsi seseorang terhadap pengelolaan sampah rumah tangga semakin negatif, maka partisipasi dalam pengelolaan sampah rumah tangga semakin rendah.

\section{Perilaku Tidak Merokok}

Keluarga yang melakukan seluruh komponen indikator perilaku tidak merokok sebanyak 51 keluarga (25,9\%). Keluarga mengetahui tentang bahaya rokok yaitu dapat menyebabkan berbagai macam penyakit,

\section{*Corresponding Author :}

Siti Mukaromah

Program Studi Pendidikan Profesi Ners

ITKES Wiyata Husada Samarinda, Indonesia

Email : sitimukaromah@itkeswhs.ac.id 
Jurnal Medika Karya IImiah Kesehatan

Vol 6, No.2, November 2021

ISSN : 2654-945X (Online), 2541-4615 (Print)

Journal homepage : http://jurnal.itkeswhs.ac.id/index.php/medika

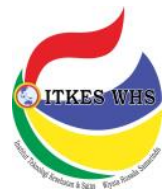

khususnya penyakit pernafasan, yang kemungkinan dapat memburuk pada masa pandemi covid-19. Pemahaman keluarga tersebut sejalan dengan pernyataan Kemenkes (2021) bahwa aktifitas merokok, baik pemakaian jenis rokok konvensional, rokok elektrik, rokok dengan pemanasan dapat mengancam kesehatan diri sendiri, keluarga, teman, maupun orang sekitar.

Penggunaan tembakau menjadi salah satu faktor risiko bagi penyakit tidak menular, seperti penyakit jantung, kanker, penyakit saluran pernafasan, dan diabetes, sehingga dapat memperparah kondisi penderita saat terpapar covid-19. Hal ini disebabkan karena merokok merusak fungsi paru-paru sedangkan covid-19 menyerang paru-paru, sehingga ketika fungsi paru-paru mengalami gangguan maka tubuh lebih sulit melawan coronavirus dan penyakit lainnya. Kebiasaan menyentuh mulut saat merokok dapat mentransfer coronavirus masuk ke dalam tubuh, demikian pula kebiasaan saling berbagi produk tembakau seperti shisha dapat menularkan coronavirus kepada orang lain (WHO, 2020).

Terpapar asap rokok berpotensi pula tertular covid-19. Asap rokok terbukti mengganggu proses migrasi sel imunitas ketika terjadi infeksi di dalam tubuh sehingga fungsi sel imunitas menurun sebagaimana yang disampaikan oleh Ketua Perhimpunan Dokter Paru Indonesia (PDPI), Agus Dwi Susanto bahwa berdasarkan data pemeriksaan patologi, perokok memiliki reseptor protein Angiotensin Converting Enzyme 2 -- ACE2 (Wuragil, 2020). Menurut Guru Besar Farmasi UGM, Prof.Dra.Apt. Zullies Ikawati, PhD, bahwa ACE2 adalah enzim yang menempel pada permukaan luar (membran) sel dan merupakan protein membran tipe I yang menembus membran sebanyak sekali (single transmembrane) dengan bagian aktif secara enzimatik berada pada permukaan sel di paru-paru dan jaringan lainnya (arteri, jantung, ginjal, usus). Coronavirus memiliki afinitas ikatan yang kuat dengan ACE2 manusia berdasarkan studi interaksi biokimia dan analisis struktur kristal (Adit, 2020).

Keluarga yang hanya melakukan sebagian komponen indikator perilaku tidak merokok berjumlah 129 keluarga (65,5\%). Keluarga tidak pernah merokok namun jarang mencari informasi tentang bahaya rokok serta keluarga juga jarang menghindar apabila ada tamu yang sedang merokok di dalam rumah. Sedangkan keluarga yang tetap merokok berjumlah 17 keluarga $(8,6 \%)$. Keluarga terutama kepala keluarga berpersepsi bahwa mereka yang terbiasa merokok bisa juga disebabkan karena pengalaman selama ini mereka baik-baik saja sehingga mereka merasa tidak perlu menghentikan kebiasaan merokok tersebut (Eva, 2019). Tidak adanya dukungan dan pendampingan dari anggota keluarga terdekat, teman, tenaga kesehatan, maupun dukungan sosial lainnya merupakan salah satu faktor penghambat dari komitmen perokok untuk berhenti merokok (Kemenkes, 2021).

\section{Perilaku Kebersihan Lingkungan}

Keluarga yang melakukan seluruh komponen indikator perilaku kebersihan lingkungan sebanyak 143 keluarga (72,6\%). Lingkungan yang bersih dan sehat membuat masyarakat yang tinggal di dalamnya merasa aman, nyaman, tenang dan bahagia (Humaira, 2020).

Lingkungan yang sehat berawal dari lingkungan rumah yang sehat. Oleh karena itu sangat perlu diperhatikan kebersihan rumah sebagai tempat individu melakukan istirahat dan aktifitas rutin di dalam rumah, sehingga dapat meminimalkan paparan risiko penyakit (Disperkimta, 2018). Lingkungan yang bersih dapat mengupayakan tubuh yang sehat sehingga memiliki pertahanan (imunitas) yang kuat dan mudah melakukan penyembuhan sendiri guna mencegah terinfeksi oleh berbagai penyakit berbahaya dan virus seperti covid-19 maupun penyakit lainnya (Humaira, 2020).

\section{*Corresponding Author :}

Siti Mukaromah

Program Studi Pendidikan Profesi Ners

ITKES Wiyata Husada Samarinda, Indonesia

Email : sitimukaromah@itkeswhs.ac.id 
Jurnal Medika Karya IImiah Kesehatan

Vol 6, No.2, November 2021

ISSN : 2654-945X (Online), 2541-4615 (Print)

Journal homepage : http://jurnal.itkeswhs.ac.id/index.php/medika

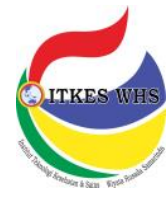

Keluarga yang hanya melakukan sebagian komponen indikator perilaku kebersihan lingkungan berjumlah 53 keluarga (26,9\%). Keluarga membersihkan lingkungan hanya setiap satu sampai dua kali saja dalam seminggu. Sedangkan keluarga yang tidak melakukan seluruh komponen indikator perilaku kebersihan lingkungan berjumlah 1 keluarga $(0,5 \%)$. Keluarga sibuk bekerja sehingga tidak sempat membersihkan lingkungan rumah. Apabila lingkungan sekitar rumah kotor maka tubuh juga rentan tertular berbagai sumber penyakit seperti covid-19 yang terjadi saat ini.

Kondisi perumahan dapat mempengaruhi kesehatan manusia, seperti halnya rumah yang dingin dan basah, tidak memiliki sirkulasi udara yang tepat, dan memiliki tingkat risiko pencemaran debu, dapat memperburuk risiko paparan penyakit. Lingkungan rumah yang kotor berisiko terhadap penurunan sistem imun sehingga mudah terpapar penyakit (Disperkimta, 2018). Hal ini sesuai dengan pernyataan Damayanti (2015) yang menyatakan bahwa pembentukan mekanisme respon imun individu akibat pajanan mikroorganisme yang bervariasi dan terjadi terus menerus di lingkungan tempat tinggal dapat menunjukkan kerentanan individu terhadap penyakit. Oleh karena itu, kemampuan menjaga kebersihan lingkungan dapat meningkatkan respon imun tubuh sehingga meminimalkan risiko terpapar penyakit termasuk covid-19.

\section{Perilaku Mengelola Stress}

Keluarga yang melakukan seluruh komponen indikator perilaku mengelola stress sebanyak 102 keluarga (51,8\%). Keluarga dapat mengelola stress dengan baik ketika timbul stress. Keluarga melakukan kegiatan positif agar stress tersebut hilang. Emosi positif berkaitan dengan kualitas kesehatan yang baik karena perasaan gembira dapat meredakan respon stress, mengurangi rasa sakit, meningkatkan daya tahan tubuh, menstimulasi peningkatan fungsi organ tubuh, dan membuat suasana hati yang baik (Kemenkes, 2019).

Keluarga yang melakukan sebagian komponen indikator perilaku mengelola stress berjumlah 88 keluarga (44,7\%). Keluarga jarang melakukan relaksasi terhadap stress namun ketika stress timbul keluarga hanya meminta pendapat dan saran dari keluarga. Adapun keluarga yang tidak mengelola stress dengan baik berjumlah 7 keluarga (3,6\%). Para ibu rumah tangga berpotensi mengalami stress saat pandemi covid-19 karena dapat dikatakan tiba-tiba semua urusan dibebankan kepada ibu rumah tangga. Namun, stress dalam keluarga tidak hanya dialami oleh ibu rumah tangga, melainkan juga dialami oleh anak yang bosan dengan model pembelajaran secara online, dan ayah sebagai kepala keluarga yang harus bekerja dari rumah atau bahkan tidak bekerja selama masa pandemi covid-19 (Moh Musim, 2020). Kondisi stress dipicu oleh peningkatan hormon kortisol, sehingga dapat menurunkan fungsi kekebalan tubuh (Lia Amalia, 2020).

Stres dapat mempengaruhi sistem imun sehingga berakibat tubuh mengalami kesulitan dan membutuhkan waktu yang lama dalam melawan penyakit. Peningkatan hormon stress berupa glukokortikoid akibat periode stress yang panjang dapat mengganggu aktivitas sel darah putih (sel limfosit T) sebagai pertahanan tubuh terakhir yang berfungsi meningkatkan imun terhadap virus atau bakteri. Oleh karena itu, pada masa pandemi covid-19 ini diperlukan upaya mengelola stress dengan tetap bahagia dan melakukan aktifitas yang menyegarkan pikiran guna menghibur diri, selain konsumsi vitamin maupun menjalankan protokol kesehatan (Homecare24, 2021).

\section{Perilaku Istirahat Yang Cukup}

Keluarga yang melakukan seluruh komponen indikator perilaku istirahat yang cukup sebanyak 110 keluarga $(55,8 \%)$. Keluarga telah mengetahui manfaat istirahat yang cukup yaitu dapat meningkatkan

\section{*Corresponding Author :}

Siti Mukaromah

Program Studi Pendidikan Profesi Ners

ITKES Wiyata Husada Samarinda, Indonesia

Email : sitimukaromah@itkeswhs.ac.id 
Jurnal Medika Karya IImiah Kesehatan

Vol 6, No.2, November 2021

ISSN : 2654-945X (Online), 2541-4615 (Print)

Journal homepage : http://jurnal.itkeswhs.ac.id/index.php/medika

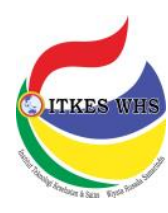

konsentrasi dalam menjalani kegiatan sehari-hari.

Adapun manfaat cukup istirahat dengan durasi tidur sekitar 7-8 jam per hari, meliputi: 1) memperkuat sistem imun dengan memperbaiki kinerja sel imun khususnya sel limfosit $T$ yang berperan dalam melawan infeksi penyakit; 2) menjaga berat badan ideal, karena meningkatnya produksi hormon leptin yang berfungsi menekan rasa lapar sehingga dapat mengendalikan nafsu makan. Kondisi kurang tidur dapat meningkatkan produksi hormon ghrelin yang berfungsi meningkatkan rasa lapar untuk mencegah tubuh kekurangan energi. Kurang tidur juga menyebabkan tubuh kelelahan sehingga enggan untuk beraktivitas; 3) menjaga kesehatan mental karena dapat membuat suasana hati yang baik, tidak mudah tersinggung atau cepat marah sehingga meminimalkan risiko gangguan suasana hati seperti depresi, dan menurunkan risiko gangguan kecemasan; 4) menurunkan risiko penyakit kronis seperti diabetes dan penyakit jantung, karena dapat menjaga kestabilan kadar glukosa dalam darah, detak jantung dan tekanan darah, serta menurunkan risiko peradangan dalam tubuh (Puji, 2021).

Keluarga yang melakukan sebagian komponen indikator perilaku istirahat yang cukup berjumlah 77 keluarga $(39,1 \%)$. Walaupun keluarga tidur dengan jam yang normal namun keluarga tersebut tidak bisa tidur dengan tenang disebabkan oleh kegelisahan saat sedang beristirahat atau tidur. Keluarga yang tidak memiliki perilaku istirahat yang cukup sebanyak 10 keluarga $(5,1 \%)$.

Kondisi pandemi covid-19 cenderung memberi dampak negatif berupa banyaknya perubahan yang terjadi dalam rutinitas sehari-hari, adanya ketidakpastian dalam hidup, rasa takut terhadap kesehatan, rasa khawatir pada situasi dan durasi pandemi yang berkepanjangan, pengalaman kehilangan pekerjaan, keharusan isolasi mandiri di rumah, tidak adanya tempat hiburan dan berkurangnya

interaksi sosial antar individu. Beragam dampak pandemi covid-19 tersebut mempengaruhi kualitas tidur seseorang yang selanjutnya berpengaruh pada kesehatan dan kehidupan pribadi, sehingga menyebabkan berkurangnya kinerja dalam kegiatan sehari-hari seperti sekolah dan bekerja, meningkatkan risiko kecelakaan dalam berkendara, memperburuk kondisi medis dan kejiwaan serta menurunkan kualitas hidup (Devi, 2020).

\section{SIMPULAN}

PHBS pada tatanan rumah tangga tetap dilaksanakan oleh keluarga di wilayah puskesmas Muara Rapak Balikpapan pada masa pandemi covid-19 ini, meskipun ketercapaian data PHBS rumah tangga belum memenuhi target. Mayoritas keluarga telah melakukan seluruh komponen tiap indikator PHBS pada masa pandemi covid-19 meliputi, perilaku mencuci tangan dengan baik dan benar $(76,1 \%)$, mengkonsumsi makanan sehat sesuai dengan gizi seimbang (53,8\%), menggunakan jamban yang bersih dan sehat $(75,6 \%)$, melakukan aktivitas fisik setiap hari $(23,4 \%)$, membuang sampah pada tempatnya $(67 \%)$, tidak merokok (51\%), menjaga kebersihan lingkungan sekitar rumah (72,6\%), menghindari dan mengelola stress dengan baik dalam kehidupan sehari-hari $(51,8 \%)$, dan istirahat yang cukup $(55,8 \%)$. Saran, diharapkan setiap keluarga dapat meningkatkan kedisiplinan penerapan PHBS pada tatanan rumah tangga selama pandemi covid-19 dengan cara melakukan seluruh komponen pada setiap indikator PHBS tatanan rumah tangga terutama perilaku aktifitas fisik, sebagai upaya peningkatan imunitas tubuh guna pencegahan paparan penyakit dan membantu pencegahan penyebaran covid-19 di lingkup individu maupun masyarakat.

\section{*Corresponding Author :}

Siti Mukaromah

Program Studi Pendidikan Profesi Ners

ITKES Wiyata Husada Samarinda, Indonesia

Email : sitimukaromah@itkeswhs.ac.id 
Jurnal Medika Karya IImiah Kesehatan

Vol 6, No.2, November 2021

ISSN : 2654-945X (Online), 2541-4615 (Print)

Journal homepage : http://jurnal.itkeswhs.ac.id/index.php/medika

\section{DAFTAR PUSTAKA}

Adit, Albertus. (2020). Guru Besar Farmasi UGM Paparkan Reseptor ACE2, "Pintu Masuk" Covid-19. http://edukasi. kompas.com, [diakses 07-10-2021]

Ahmad Marzuki, dkk. (2016). Manajemen PHBS Tatanan Rumah Tangga di Kelurahan Kurao Pagang Padang. Journal Endurance, Volume 1 (3) Oktober 2016

Atikah P \& Eni R. (2012). PHBS Perilaku Hidup Bersih dan Sehat. Yogya: Nuha Medika

Bahraini. (2020). Cara Mengelola Sampah untuk Cegah Penyebaran Covid-19. Tersedia dalam www.waste4change.com [Diakses 07-10- 2021].

Benny, Berlina. (2020). Gambaran Perilaku Hidup Bersih dan Sehat (PHBS) dalam Pencegahan Penularan Covid-19. Jurnal Kesehatan Karya Husada (JKKG), Vol. 8 (2) Hal 34-53

Dahlan, Sopiyudin. (2016). Langkah-langkah Membuat Proposal Penelitian Bidang Kedokteran dan Kesehatan. Jakarta: CV. Sagung Seto

Damayanti, Ndaru Andri. (2015). Regulasi Respons Imun Subyek di Pemukiman Kumuh: Studi Imunitas Seluler pada Kultur Sel Darah yang Distimulasi Malaria, Vaksin BCG dan LDL. Disertasi. Jakarta: Universitas Indonesia

Devi H. (2018). Perilaku Masyarakat Dalam Menjaga Kebersihan Lingkungan Lingkungan Pantai Kecamatan Sasak Ranah Pasisie Kabupaten Pasaman Barat. Jurnal Buana, Vol. 2 (2) Hal 495-506

Disperkimta. (2018). Kebersihan Lingkungan. Tersedia dalam: www.disper kimta.bule lengkab.go.id [Diakses 07-10-2021].

Disperkimta. (2019). 7 Tips Menjaga Lingkungan Agar Tetap Sehat dan Nya man. Tersedia dalam: www.disper kimta. bulelengkab.go.id [Diakses 01-03- 2019].

Edi Sutoyo. (2020). Upaya peningkatan pemahaman PHBS terkait pengelolaan sampah di lingkungan masyarakat desa leuwisaden. Jurnal Pengabdian Pada Masyarakat, Vol. 4 No. 1

Elisabeth Surbakti, dkk. (2020). Belajar dari Covid-19 Perspektif Ekonomi dan Kesehatan: Upaya Pencegahan Penularan Covid-19 dalam Tatanan Keluarga. Medan: Yayasan Kita Menulis

Hartati Bahar, (2020). Menyusun dan Mengembangkan Materi Penyuluhan Kesehatan: Memaksimalkan Peran PHBS Tatanan Rumah Tangga dalam Pencegahan Covid-19. Kendari: Guepedia Homecare24. (2021). Ternyata Benar! Stres Bisa Picu Covid-19 Bertambah Parah. Tersedia dalam: www.homecare24.id [Diakses 07-10-2021]

Humaira, dkk. (2020). Pentingnya penerapan phbs dalam menghadapi pandemi covid-19 di lingkungan masyarakat. UNES

Kemenkes RI. (2014). Permenkes RI Nomor 41 Tahun 2014 tentang Pedoman Gizi Seimbang.

Kemenkes RI. (2014). Permenkes RI Nomor 3 Tahun 2014 tentang Sanitasi Total Berbasis Masyarakat.

Kemenkes RI. (2015). Infodatin: Perilaku Merokok Masyarakat Indonesia. http:// www.depkes.go.id, [diakses 18-03-2019]

Kemenkes RI. (2016). PHBS. Tersedia dalam: https://promkes.kemkes.go.id [Diakses 01-01-2016].

Kemenkes RI. (2016). Istirahat Cukup. Terse dia dalam www.p2ptm.kemkes.go.id [Diak ses 10-10-2016].

Kemenkes RI. (2016). Kelola Stress. Tersedia dalam www.p2ptm.kemkes.go.id [Diakses 10-10-2016].

Kemenkes RI. (2016). Talkshow Iklan Layanan Masyarakat: Rokok Mengancurkan Tubuh mu. Tersedia dalam: https://sehatnegeriku. kemkes.go.id [Diakses 18-09-2016].

Kemenkes RI. (2017). Hari Gizi Nasional 20 17: Ayo Makan Sayur dan Buah Setiap ha ri. Tersedia dalam: https://kemkes.go.id [Diakses 25-01-2017].

\section{*Corresponding Author :}

Siti Mukaromah

Program Studi Pendidikan Profesi Ners

ITKES Wiyata Husada Samarinda, Indonesia

Email : sitimukaromah@itkeswhs.ac.id 
Jurnal Medika Karya IImiah Kesehatan

Vol 6, No.2, November 2021

ISSN : 2654-945X (Online), 2541-4615 (Print)

Journal homepage : http://jurnal.itkeswhs.ac.id/index.php/medika

Kemenkes RI. (2018). Bagaimana Istirahat Yang Cukup? Tersedia dalam: www.p2 ptm.kemkes.go.id [Diakses 29-07-2018]

Kemenkes RI. (2018). Pedoman Pembinaan Krida Bina Lingkungan Sehat. Kementrian Kesehatan Republik Indonesia: Direktorat Jendral Kesehatan Masyarakat.

Kemenkes RI. (2018). Cara Menghindari Pengaruh Untuk Merokok. Tersedia dalam: www.p2ptm.kemkes.go.id [Diakses 04-06-2018]

Kemenkes RI. (2018). 'Data Informasi Kesehatan Indonesia 2018', Profil Kesehatan Indonesia, 53(9).

Kemenkes RI. (2019). Anjuran Menkes Soal Durasi Waktu Olahraga. Tersedia dalam: https://kemkes.go.id [Diakses 07-10-21].

Kemenkes RI. (2019). Dengan Gembira, Tubuh Tetap Sehat. Tersedia dalam: https:// kemkes.go.id [Diakses 07-10-2021].

Kemenkes RI. (2020). Kepmenkes RI Nomor HK.01.07/MENKES/382/2020 tentang Protokol Kesehatan Bagi Masyarakat di Tempat dan Fasilitas Umum dalam rangka Pencegahan dan Pengendalian Corona Virus Disease 2019 (Covid-19).

Kemenkes RI. (2021). Peringati Hari Tanpa Tembakau Sedunia, Kemenkes Targetkan 5 Juta Masyarakat Berhenti Merokok. Tersedia dalam: https://kemkes.go.id [Diakses 0710-2021].

Lia Amalia, Dkk. (2020). Analisis gejala klinis dan peningkatan kekebalan tubuh untuk mencegah penyakit covid-19. Jambura Journal of health sciences and research, Volume 2 No.2

Lia Rosa, Dkk. (2020). Sosialisasi Perilaku Cuci Tangan Pakai Sabun di Desa Sawo Sebagai-Bentuk Kepedulian Terhadap Masyarakat Ditengah Mewabahnya Virus Covid-19. Jurnal Abdimas Mutiara Vol. 1 Nomor: 2, September 2020

Muh. Fajaruddin N. (2019). Perilaku Hidup Bersih dan Sehat (PHBS) Pada Tatanan Rumah Tangga Masyarakat Desa Parang
Baddo. Jurnal Nasional IImu Kesehatan (JNIK), Volume 1, Edisi 32019

Nisal, P. N. (2019). Analisis Pelaksanaan Perilaku Hidup Bersih dan Sehat (PHBS) Tatanan Rumah Tangga Di Puskesmas Alahan Panjang Kabupaten Solok. Skripsi.

Nugraha, Aditya, dkk. (2018). Persepsi dan Partisipasi Masyarakat terhadap Pengelolaan Sampah Rumah Tangga melalui Bank Sampah. Jurnal Pengelolaan Sumber Daya Alam dan Lingkungan. Vol 8 , No 1, April 2018.

Nurwita Utami. (2020). PHBS Selama Masa Pandemi. Indonesia Environment \& Ener gy Center tersedia dalam: http://environ ment-indonesia.com [Diakses 04-05-'20].

Putri Wulandini S. (2018). Faktor-Faktor yang Berhubungan dengan Perilaku Hidup Bersih dan Sehat (PHBS) di Desa Kualu Kecamatan Tambang Kampar. Vol.8 No.2. Keperawatan, Univ. Abdurrab, Pekanbaru

Ulina, Marna. (2018). Implementasi Perilaku Hidup Bersih dan Sehat (PHBS) pada Tatanan Rumah Tangga di Wilayah Kerja Puskesmas Medan Johor. Skripsi. USU

Umar Zein, Emir El Newi. (2019). Ilmu Kese hatan (Memahami Gejala, Tanda dan Mitos). Yogyakarta: CV Budi Utama

Sugiyono (2015). Metode Penelitian Kombinasi (Mix Methods). Bandung: Alfabeta.

Widia Astuti AW, dkk. (2020). Hubungan tingkat pengetahuan tentang phbs dengan penggunaan jamban sehat. Jurnal IImiah Wijaya Volume 12 Nomor $1 \mathrm{Hal} 47$ - 55.

WHO. (2020). Pernyataan WHO: Penggunaan tembakau dan COVID-19. Tersedia dalam www.who.int [Diakses 07-10-2021].

Wuragil, Zacharias. (2020). Begini Perokok Bisa Tularkan Virus Corona. Tersedia dalam www.tekno.tempo.co [Diakses 07-10-2021].

\section{*Corresponding Author :}

Siti Mukaromah

Program Studi Pendidikan Profesi Ners

ITKES Wiyata Husada Samarinda, Indonesia

Email : sitimukaromah@itkeswhs.ac.id 